\title{
Internalizing Environmental Literacy of Elementary Students During Covid-19 Pandemic
}

\author{
Uus Kuswendi*, Hana Sakura Putu Arga \\ Pendidikan Guru Sekolah Dasar, IKIP Siliwangi \\ *Corresponding author. Email: uus@ikipsiliwangi.ac.id
}

\begin{abstract}
The emergence of Covid-19 pandemic has an impact on changes in the learning process. On of such changes is the lack of attention to the socialization of environmental literacy, which is usually done in schools. Environmental literacy can foster a sense of caring for the environment as students are taught to take actions to minimize environmental damage. In spite of the pandemic, teachers should continue to foster environmental literacy to their students. Thus, this study aims to foster the environmental literacy of elementary school students through the use of used goods. Using experimental research method, the study took samples from fifth grade elementary school students who were randomly selected. Data collection techniques in this research used questionnaires and rubric of skill. The analysis was by inferencing from statistical data using content validity. Students are categorized as having good environmental literacy if they have met several indicators of environmental literacy aspects in the form of cognitive, attitude, and behavioral aspects. The results of this research indicate that the activity of utilizing used goods affects the students' environmental literacy. The activity of utilizing scraps has a good effect on students because they have psychomotor activities that can reduce the sense of boredom of learning. The most important thing from using used goods is that the student's environmental literacy continues to develop even though learning takes place online.
\end{abstract}

Keywords: Environmental literacy, elementary school, used goods

\section{INTRODUCTION}

An excessive human activity to meet their daily needs often cause damage to the environment, one of which is environmental pollution. Rivers contaminated with household waste and garbage and reduced supplies of clean water are just a few of the many environmental problems that must be resolved (Afrianda, Yolida, \& Marpaung, 2019). Garbage is one of the problems that never ends. Garbage is something that is not resolved because many materials are not environmentally friendly, making it difficult to decompose. In addition, community skills in waste management are still low. The community has not been able to sort out biodegradable and nonbiodegradable waste, trash that can be stockpiled or waste that can be recycled. The lack of knowledge about sorting waste does not only happen to the community but also to elementary school students. Unfortunately, schools are a significant contributor to waste. Every day, schools generate a lot of waste because students tend to have consumptive behavior. Besides, schools also do not provide direction to students regarding waste problems. There are still many schools that pay less attention to the school environment even though the formation of character caring for the environment can start from school, especially in elementary schools.

This, and many other environmental problems cause the government to make efforts and commitment to protect the environment from damage through education. Pendidikan Lingkungan Hidup (Environmental Education) is an educational program to foster students to have knowledge, attitudes, awareness of skills and behavior that are rational and responsible about the mutual influence between residents and the environmental in various aspects of human life (Daryanto, 2013). Environmental education is integrated into the subject material taught to the students. As such, school should facilitate students to love the environmental more. One way to show environmental care is by keeping the environment clean and being able to classify waste according to its type. Schools need to provide trash bins of two different types, such as dry trash and wet trash (Nurhayati, 2013). Thus, students will be trained to sort waste. Sorting waste is certainly not a simple matter because it is proven that waste has a 
significant impact on environmental sustainability. If the garbage is increasingly mounting and cannot be destroyed, it will cause new environmental pollution. Therefore, education about sorting waste needs to be implemented from an early age (Daryanto, 2013).

Environmental literacy is a conscious attitude to protect the environment. This literacy is not only being knowledgeable about the environmental but also being responsive and able to provide solutions to environmental issues. Students as part of society are prepared as the next generation and agents of change in society need to be equipped with environmental literacy skills (Kusumaningrum, 2018). Environmental literacy is not only about human interaction with the environmental but interaction with oneself. In environmental literacy, we do not only act to preserve the environmental but we act to keep ourselves clean first. In addition, environmental literacy is related to environmental cleanliness in the community can be carried out by teachers by changing used goods into usable items (Ngalu, 2019).

During the pandemic, learning about preserving the environmental has become increasingly difficult to carry out and monitor. Even so, there are various ways to keep educating students about the importance of protecting the environmental. Environmental literacy remains an important aspect, especially when the virus is currently raging in various countries. It is hoped that environmental literacy will help stop the virus. Meanwhile, virtual learning is quite influential on students' stress levels. One way to overcome boredom while internalizing environmental literacy is by having the activity of processing used goods. It is hoped that this activity can not only develop students' environmental literacy but can provide new activities to students so that this activity is expected to reduce students' stress.

Regarding this issue, this study aims to measure the environmental literacy of elementary school students through the use of used goods during the pandemic. The researchers want to compare the environmental literacy abilities of students who get used goods processing activities with students who do not get used goods processing activities. In doing so, this study used a quasiexperimental research.

\section{METHOD}

This study used a quasi-experimental research method. Sugiyono (2010) explains that in the quasiexperimental method, there are two designs, namely the time-series design and the nonequivalent control group design. In this study, the researchers used a quasiexperimental with a nonequivalent control group design. Before giving the treatment, the researcher first gave the test to the experimental group and the control group as a pretest, to know the initial conditions of the group. Then after the pre-test, the two groups were given the post-test to know the condition of the group after being given the treatment. In the experimental group, learning was carried out by using used goods, while in the control class learning activities were carried out using a direct learning model. The test results of the two groups were analyzed and described to measure the effectiveness of the use of used goods to foster environmental literacy for elementary school students.

According to Mulyatiningsih (2011), population is a group of people, animals, or objects that have certain characteristics to be studied. The population will be the area for generalizing the conclusions of the research results. The population is a group of subjects and objects along with their characteristics that researchers can use to draw generalizations and conclusions on research results. Based on this statement, the researcher determined that the population in this study were the fifth-grade elementary school students in Cimahi District. Furthermore, the sample is a portion of the population. For example, the population in an area has a sample in the form of employees in certain organizations or teachers and students in certain schools (Sugiyono, 2010).

The sample selection in this study using a purposive sampling technique. Purposive sampling technique is selecting samples through various considerations such as the number of participants, student characteristics, or school background (Creswell, 2015). The researchers chose grade V students as research subjects because the characteristics of grade $\mathrm{V}$ students were appropriate for carrying out project-based activities. Also, the use of purposive sampling is due to the current learning that does not allow random grouping due to the coronavirus.

Then, the research instrument used three types of tests, namely cognitive tests, attitudes, and skills. Cognitive test is a test to measure students' knowledge about the environmental and its problems. This test uses an objective test in the form of a description. Attitude tests are used to measure the student's conative aspects, namely students' attitudes about caring for themselves as a part of environmental literacy. The attitude test used a questionnaire that was filled out by each student. Meanwhile, the skills test is a test to measure students' skills in using used goods. Students practice managing until it becomes a valuable item. Skills tests are assessed using a skills rubric. This test instrument was validated using construct validity and content validity.

The data analysis in the study used descriptive statistics and inference to assess the series of tests that students had carried out. Then, inference statistics are used to test the research hypothesis. The research hypothesis is as follows.

H0: The use of used goods has no effect towards the environmental literacy of elementary school students 
Ha: The use of used goods affects on environmental literacy of elementary school students

\section{FINDINGS AND DISCUSSION}

The followings are the results of research after the implementation of the use of used goods as an effort to foster environmental literacy for elementary school students.

Table 1. Statistical test results

\begin{tabular}{|l|l|l|l|}
\hline \multicolumn{1}{|c|}{ Test } & Experiment & Control & \multicolumn{1}{|c|}{ Information } \\
\hline Normality & 0,016 & 0,009 & $\begin{array}{l}\text { Not normally } \\
\text { distributed }\end{array}$ \\
\hline $\begin{array}{l}\text { Mann } \\
\text { Whitney }\end{array}$ & \multicolumn{2}{|c|}{0,000} & $\mathrm{H}_{0}$ rejected \\
\hline
\end{tabular}

Table 1 shows the statistical test result. The results of the environmental literacy normality test for the experimental and control class students showed that the data were not normally distributed so that the next statistical test used the Mann Whitney test to answer the research hypothesis. The Mann Whitney test shows the statistical calculation result is less than 0.05 , so the research hypothesis (H0) is rejected. Thus, the results showed that the environmental literacy of the experimental class students experienced a quite good change after the implementation of the used goods utilization activities. The results of statistical tests have shown the effect of the use of used goods on the environmental literacy of elementary school students.

According to Miller (1997), a person's environmental literacy ability can be measured through four components, namely (1) Environmental knowledge which includes environmental basics; (2) Attitudes towards the environmental which include views of the environmental, sensitivity to environmental conditions, and feelings towards the environmental; (3) cognitive skills which include identification of environmental problems, environmental analysis and implementation of planning; and (4) behavior which includes concrete actions against the environmental. These components are a reference used to assess a person's environmental literacy skills.

Meanwhile, in this study, environmental literacy indicators are divided into three, namely cognitive, attitude, and behavioral aspects. The cognitive aspect is students' basic knowledge about the environmental as well as identifying problems and finding appropriate solutions to environmental problems. The attitude aspect is related to, the views of students in preserving the environmental and caring for themselves. Behavioral aspects relate to the actions taken by students to reduce waste problems, namely in the form of managing waste into more useful items. The following is a comparison of the scores between the experimental class and the control class.

Table 2. Experiment class scores and control classes

\begin{tabular}{|l|c|c|}
\hline \multicolumn{1}{|c|}{ Aspects } & Experiment Class & Control Class \\
\hline Cognitive & 85 & 70 \\
\hline Attitude & 90 & 75 \\
\hline Behavior & 90 & 60 \\
\hline
\end{tabular}

Table 2 shows the scores for the experimental class and control class. The score obtained explains that the experimental class has higher scores from various aspects than the control class students. In the aspect of behavior, the comparison of scores between the experimental class and the control class is quite different. Next, the researcher categorized the students' environmental literacy.

In the cognitive aspect, the researchers measure students' knowledge about environmental literacy. the researchers asked about environmental problems around them to global environmental problems and how students handled these problems based on the knowledge they had. Students with good environmental literacy knowledge could answer these questions logically according to their capacity. For example, the researcher gave questions related to the issue of global warming, and then the students were asked to explain their knowledge on the issue.

In the attitude aspect, students fill out questionnaires related to daily activities that show environmental literacy attitudes. Environmental literacy attitudes in the questionnaire are in the form of attitudes at home, environment, and school. Researchers can assess the synchronization of attitudes and cognitive aspects to measure the level of environmental literacy of students. In several studies, it was found that students who have a good environmental care attitude can explain the importance of an environmental care attitude even though the language used is simple. Meanwhile, the behavior is related to student's actions in processing waste or used goods into more valuable items. After the research, it is expected that students can demonstrate environmental literacy behavior without always being given directions. Students already have the initiative to process waste and used goods in their environment into more valuable items such as works of art or items that have a sale value.

The results of this study indicate that the experimental class students are in the second category, namely the nominal environmental literacy. In this category, students can already recognize simple terms about the environmental and can identify environmental problems and propose solutions to solve environmental problems simply. Then, students can be invited to work together in maintaining cleanliness which includes personal hygiene 
and environmental cleanliness. Meanwhile, the control class students are in category one, namely environmental illiteracy. In this category, students already have a little understanding of environmental problems and have simple ideas about solutions to dealing with environmental problems. However, students have not taken actions that reflect environmental literacy.

In the cognitive aspect, students in the experimental class have good knowledge in identifying environmental problems and can explain solutions to environmental problems. In the aspect of attitude, students in the experimental class obtained excellent scores. The results of filling out the questionnaire indicate that students can implement environmental literacy at home and school. In behavior aspect, experimental class students take environmental literacy actions in the form of using used goods. One way to develop students' environmental literacy is to carry out activities to recycle materials that are no longer useful (waste) into other materials that are more useful. Examples of recycling activities such as processing scraps of rags into blankets, rags, doormats, or processing used bottles / plastics into plastic pellets to be reprinted into buckets, hangers, pots, etc. or processing used paper into paper pulp and reprinted into paper with lower quality (Arisona, 2018). The activity of using used goods is carried out by students with the guidance of the teacher. Students carry out activities to use used goods at home with remote guidance. Students make crafts from used items in the form of straws, drinking bottles, cans, ice cream sticks, and used magazines.

The results indicate that the use of used goods can develop environmental literacy for elementary school students. Previous research by Sari and Widiyatmoko (2014) also carried out the use of used goods to make teaching aids for junior high school students to improve the character of caring for the environment. The results of the study prove that the use of used goods can improve the environmental care character of junior high school students. Furthermore, Retno, Utami, and Yuhanna (2019) conducted qualitative research to observe the application of green living to students' environmental care behavior. Programs designed to realize student independence are self-development, maintaining cleanliness, habituation programs and recycling waste. The existence of a green living program in schools affects students' environmental care behavior.

Another research conducted by Asih (2018) is about waste management activities in schools regarding the character of caring for the environment. The results showed that the waste management program in schools could improve students' environmental care character. Habituation activities at school consist of routine activities, spontaneous activities, and programmed activities. Routine activities are activities that are continuously carried out at school, such as clean Friday activities, class pickets, and pickets to pick up trash around the school environmental. Then spontaneous activities are activities that can be carried out without being limited by time, place and space, for example disposing of used snacks in their place, picking up scattered trash. Then the character of caring for the environmental through waste management is carried out in programmed activities, namely schools holding waste management programs for recycling.

The results of this study are in line with the research results of Veisi et al. (2018) which shows that environmental literacy activities in schools can improve aspects of students' knowledge about the environmental. In this study, researchers prepared cases and videos featuring environmental issues. Environmental issues discussed include pollution, energy use, waste recycling, and other activities related to environmental conservation. In this study, the knowledge aspect of students is in the nominal category of environmental literacy, while the research conducted by Veisi et al. (2018) students is in the category of functional environmental literacy. The results of this study, students have enough environmental knowledge category while in the previous research students were in good category.

This is different from the research conducted by Baro'ah and Qonita (2020) which implements a school environmental program without plastic. The implementation of nurturing the character of loving the environment in children through a school environmental program without plastic waste is carried out by processing waste, requiring students to bring tumblers, providing refill water stations, and making plastic waste banks. The goal of the environmental program without plastic waste is that students get used to loving the environmental as early as possible and have a healthy lifestyle. School environmental activities without plastic waste are carried out as long as students are in the school environmental and are expected to become habits that have a good impact on students when they are in the family and community environmental.

Children can be more creative in producing recycled waste products because they have high imagination. On the other hand, children who understand this waste management, directly or indirectly, can pass on their knowledge to friends, even relatives, and their parents. This can create students who care more about waste. (Puspitasari et al., 2017). The results of this study are also able to encourage students to be more creative in processing used goods. This was shown by the complicated student work at the end of the research meeting. Unlike the first day of research, students still need directions and examples from researchers in processing waste or used goods. Meanwhile, at the third meeting until the end, students can process used goods according to their imagination. 
Garbage in schools is a source of waste which plays a significant role in environmental pollution. The existence of garbage in an environmental cannot be avoided. The presence of garbage can cause soil and water pollution, cause unpleasant odors, become a den of animals which are a source of disease, and disturb beauty, but the presence of garbage can be reduced. A simple effort that can be done to minimize waste is to separate organic waste and inorganic waste. Organic waste can be used as compost, while inorganic waste can be used as various recycled creations (Purwanti \& Hawa, 2019).

The process of reprocessing waste is carried out so that the waste can provide material value for reuse. This process can free or reduce the amount of waste (Suryani, 2014). In most communities, household waste is recycled into something useful in a simple and effective way. Various types of waste such as leaves, plastic bottles, metal bottles, paper and food scraps, can be separated into organic and inorganic waste. Organic waste can also be processed biologically into compost or liquid leachate fertilizer. Activities in waste management can be carried out in various ways, one of which is by carrying out recycle activities (Wintoko, 2012).

One of the characters that is no less important to cultivate in students from an early age is environmental literacy. Environmental literacy is in the form of attitudes and actions that always try to prevent damage to the surrounding natural environmental (Yuliarti, 2009). In addition, developing efforts to repair natural damage that has occurred and always wanting to aid other people and communities in need. Environmental literacy will foster an attitude or character that cares about the environmental.

The character of caring for the environmental is a character that must be implemented for schools at every level of education. Students must have a caring attitude towards the environmental by improving the quality of the environmental, increasing awareness of the importance of caring for the environmental and having initiatives to prevent environmental damage. Character education caring for the environmental is instilled in students from an early age so that they can wisely manage the natural resources around them, and to foster a sense of responsibility for the interests of future generations to come. When the character of caring for the environmental has grown into a strong mentality, it will underlie one's behavior in everyday life (Listyarti, 2014).

\section{CONCLUSION}

Schools are a fairly high producer of waste. Therefore, schools need to be responsible for reducing waste so that waste problems can be reduced. Waste reduction activities can be carried out from the simplest things such as sorting organic and inorganic waste.
Organic waste can be destroyed by burying it because this waste decomposes more quickly. Meanwhile, inorganic waste needs special handling because it cannot be broken down. Schools can contribute by inviting students to manage waste. This study aims to develop students' environmental literacy through the use of used goods. The results of the study explain that the activities of using used goods affect the environmental literacy of elementary school students. Environmental literacy is a person's skill to protect and overcome environmental problems. Students who have good environmental literacy will usually grow to be someone who really loves the environmental or cares about the environmental. A caring attitude towards the environmental can be obtained through a school refraction. This study not only provides students with ways to manage waste but also provides knowledge about the environmental from the basic to the highest. Through the activity of using used goods, it is hoped that students can have better motor activities than just using cell phones. After this research is over, hopefully the students have the initiative to recycle waste.

\section{REFERENCES}

Afrianda, R., Yolida, B., \& Marpaung, R. R. (2019). Pengaruh Program Adiwiyata terhadap Literasi Lingkungan dan Sikap Peduli Lingkungan. Jurnal Bioterdidik: Wahana Ekspresi Ilmiah, 7(1), 32-42.

Arisona, R. D. (2018). Pengelolaan Sampah 3R (Reduce, Reuse, Recycle) pada Pembelajaran IPS Untuk Menumbuhkan Karakter Peduli Lingkungan. Al Ulya: Jurnal Pendidikan Islam, 3(1), 39-51.

Asih, N.T.R.I. (2018). Pengelolaan sampah di sekolah. [Unpublished Undergraduate research paper]. IAIN Purwokerto.

Baro'ah, S., \& Qonita, S. M. (2020). Penanaman CiLi (Cinta Lingkungan) Pada Siswa Melalui Program Lingkungan Sekolah Tanpa Sampah Plastik. JURNAL PANCAR (Pendidik Anak Cerdas dan Pintar), 4(1).

Creswell, J. (2015). Riset pendidikan: Perencanaan, pelaksanaan, dan evaluasi riset kualitatif \& kuantitatif. Yogyakarta: Pustaka Pelajar.

Daryanto, S. (2013). Pengantar Pendidikan Lingkungan Hidup. Yogyakarta: Gava Media.

Kusumaningrum, D. (2018). Literasi Lingkungan Dalam Kurikulum 2013 Dan Pembelajaran IPA di SD. Indonesian Journal of Natural Science Education (IJNSE), 1(2), 57-64.

Listyarti, R. (2012). Pendidikan Karakter dalam Metode Aktif, Inovatif, dan Kreatif. Jakarta: Erlangga, 4, 1. 
Miller Jr, G.T., (1997). Environmental science. Sixth Edition. United States of America: Wadsworth Publishing Company.

Muyatiningsih. (2011). Metode penelitian terapan bidang pendidikan. Bandung: ALFABETA.

Ngalu, R. (2019). Peningkatan kesadaran dan kreativitas siswa sekolah dasar tentang sampah melalui pelatihan pengolahan sampah menjadi benda bernilai di desa Golo Ropong. Jurnal Pengabdian Masyarakat, 2 (2),89-178.

Nurhayati. (2013). Pencemaran Lingkungan. Bandung: Yrama Widya

Purwanti, K. Y., \& Hawa, A. M. (2019). Peningkatan Pengetahuan dan Keterampilan Pembuatan "Basabokas" untuk Siswa Kelas 5 Sekolah Dasar. Jurnal Surya Masyarakat, 2(1), 45-49.

Puspitasari, R. L., Sugoro, I., Elfidasari, D., \& Perdana, A. T. (2018). Pengabdian Kepada Masyarakat Pelatihan Daur Ulang Sampah pada Siswa Sekolah Dasar di SDN 03 Cempaka Putih, Ciputat, Tangerang Selatan. Jurnal Al-Azhar Indonesia Seri Sains dan Teknologi, 4(2), 91-94.
Retno, R.S., Utami, S., \& Yuhanna, W.L. (2019). Analisis kemandirian siswa sekolah dasar melalui penerapan green living. In Prosiding Seminar Nasional SIMBIOSIS (Vol. 4).

Sari, A. M., \& Widiyatmoko, A. (2014). Pengembangan Alat Peraga Pemanasan Global Berbahan Bekas Pakai Untuk Menanamkan Karakter Peduli Lingkungan. Unnes Science Education Journal, $3(3)$.

Sugiyono, D. (2010). Metode penelitian kuantitatif dan $R \& D$. Bandung: Alfabeta.

Suryani, A. S. (2014). Peran bank sampah dalam efektivitas pengelolaan sampah (studi kasus bank sampah Malang). Jurnal Aspirasi, 5(1), 71-84.

Veisi, H., Lacy, M., Mafakheri, S., \& Razaghi, F. (2019). Assessing environmental literacy of university students: A case study of Shahid Beheshti University in Iran. Applied Environmental Education \& Communication, 18(1), 25-42. http://doi.org/10.1080/1533015X.2018.1431163

Wintoko, B. (2012). Panduan Praktis Mendirikan Bank Sampah. Yogyakarta: Pustaka Baru Pres.

Yuliarti, N. (2009). 1001 cara menghasilkan pupuk organik. Yogyakarta: Andi Offset. 